E International

\title{
What Do We Mean by a Level Playing Field in International Aviation?
}

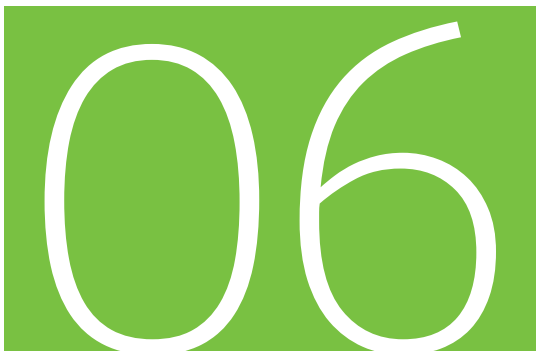

Discussion Paper 2015• 06

Mike Tretheway and

Robert Andriulaitis

InterVISTAS Consulting Inc.

Vancouver, Canada 


\section{What Do We Mean by a Level Playing Field in International Aviation?}

Discussion Paper No. 2015-06

Mike TRETHEWAY, Robert ANDRIULAITIS

InterVISTAS Consulting Inc., Vancouver, Canada

February 2015 


\section{THE INTERNATIONAL TRANSPORT FORUM}

The International Transport Forum at the OECD is an intergovernmental organisation with 54 member countries. It acts as a strategic think-tank, with the objective of helping shape the transport policy agenda on a global level and ensuring that it contributes to economic growth, environmental protection, social inclusion and the preservation of human life and well-being. The International Transport Forum organises an Annual Summit of ministers along with leading representatives from industry, civil society and academia.

The International Transport Forum was created under a Declaration issued by the Council of Ministers of the ECMT (European Conference of Ministers of Transport) at its Ministerial Session in May 2006 under the legal authority of the Protocol of the ECMT, signed in Brussels on 17 October 1953, and legal instruments of the OECD.

The Members of the Forum are: Albania, Armenia, Australia, Austria, Azerbaijan, Belarus, Belgium, Bosnia and Herzegovina, Bulgaria, Canada, Chile, China (People's Republic of), Croatia, Czech Republic, Denmark, Estonia, Finland, France, Former Yugoslav Republic of Macedonia, Georgia, Germany, Greece, Hungary, Iceland, India, Ireland, Italy, Japan, Korea, Latvia, Liechtenstein, Lithuania, Luxembourg, Malta, Mexico, Republic of Moldova, Montenegro, Netherlands, New Zealand, Norway, Poland, Portugal, Romania, Russian Federation, Serbia, Slovak Republic, Slovenia, Spain, Sweden, Switzerland, Turkey, Ukraine, United Kingdom and United States.

The International Transport Forum's Research Centre gathers statistics and conducts co-operative research programmes addressing all modes of transport. Its findings are widely disseminated and support policymaking in member countries as well as contributing to the Annual Summit.

\section{Discussion Papers}

The International Transport Forum's Discussion Paper Series makes economic research, commissioned or carried out at its Research Centre, available to researchers and practitioners. The aim is to contribute to the understanding of the transport sector and to provide inputs to transport policy design.

ITF Discussion Papers should not be reported as representing the official views of the ITF or of its member countries. The opinions expressed and arguments employed are those of the authors.

Discussion Papers describe preliminary results or research in progress by the author(s) and are published to stimulate discussion on a broad range of issues on which the ITF works. Comments on Discussion Papers are welcomed, and may be sent to: International Transport Forum/OECD, 2 rue André-Pascal, 75775 Paris Cedex 16, France.

For further information on the Discussion Papers and other JTRC activities, please email: itf.contact@oecd.org

The Discussion Papers can be downloaded from: www.internationaltransportforum.org/jtrc/DiscussionPapers/jtrcpapers.html

The International Transport Forum's website is at: www.internationaltransportforum.org

This document and any map included herein are without prejudice to the status of or sovereignty over any territory, to the delimitation of international frontiers and boundaries and to the name of any territory, city or area. 



\section{Table of Contents}

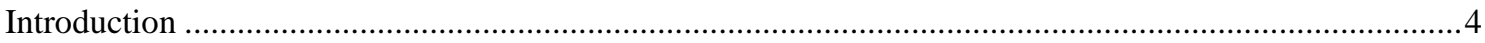

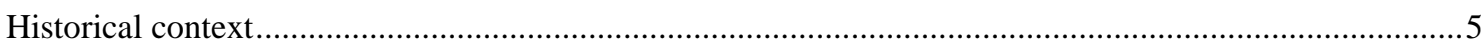

Factors affecting the level playing field that should not be considered an issue ................................... 7

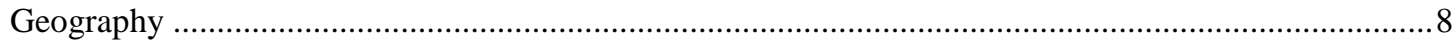

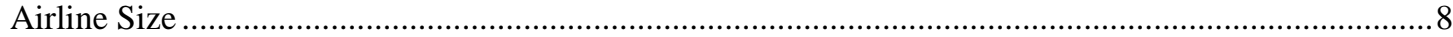

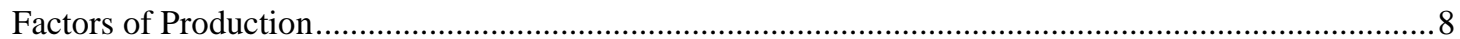

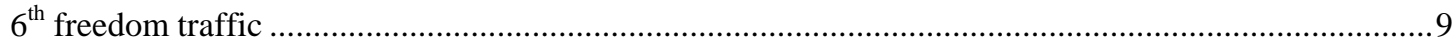

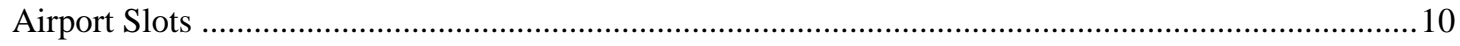

Legitimate Concerns Raised by Level Playing Field .................................................................... 11

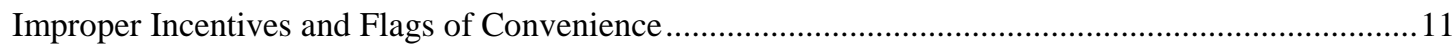

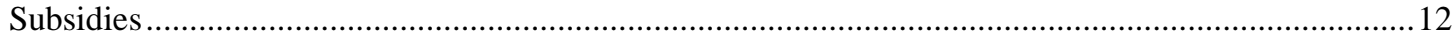

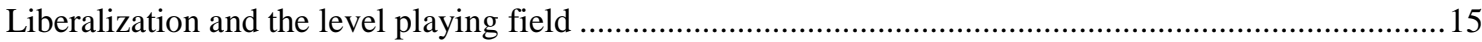

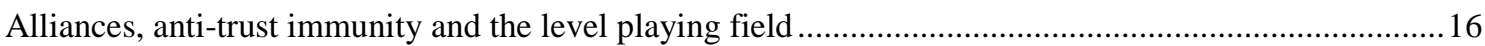

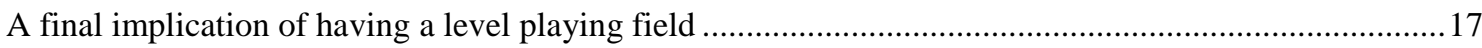

Conclusions

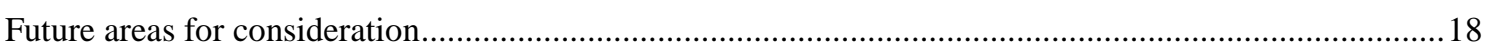

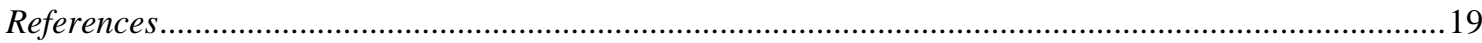




\section{Introduction}

The issue of a "level playing field" has re-emerged as a major issue in international aviation. This issue has been around for decades but has been raised in recent policy debates. One policy forum in which this has been raised is the European Commission's proposed revision to Regulation $868 / 2004$, which some view as a response to allegations by some legacy carriers to the rapid growth of the Middle East carriers such as Emirates, Etihad Airways and Qatar Airways. Another dimension to the concern over the level playing field is the evolution in foreign ownership rules, such as the type of treaty clauses being negotiated by the European Union. Could broader acceptance of service by carriers owned by third-party nationals create conditions for a flag of convenience regime of the kind that characterises parts of maritime liner shipping? The flag of convenience issue has been discussed in the U.S. media with regard to Norwegian Air Shuttle. Norwegian's long haul services are operated by subsidiaries Norwegian Long Haul AS and Norwegian International Ltd. The former is registered in Norway while the latter is registered in Ireland and operates flights for its parent. Some long haul flights have operated with contract flight attendant labour based in Thailand.

On the flip side Findlay and Goldstein (2004), in looking at the aviation sector in Asia, point out that a more liberal foreign ownership approach would provide funding and management capacity to support the adjustment process of incumbent airlines dealing with key pressures to change, including demand side shocks and the rise of low cost carriers. They also note that a greater role for private investment, including foreign investment, will support the movement to regulatory reform.

The level playing field issue has received some, but limited attention in the literature. Some see the issue as one of a disguised attempt to seek protectionism (e.g., de Wit 2013). Others see it in light of a post-mercantilist strategy (Dresner). Legacy carriers, and in particular their employees, view the issue as one of enhancing the aviation business environment and defending local jobs (ALPA, 2013).

In the debate thus far, there have been allegations of a lack of a level playing field in some markets. Some have tried to link aviation liberalisation in general with fair competition and level playing field issues, suggesting a desirability to halt or even reverse further liberalisation of air access. However, no one has precisely defined what constitutes a level playing field in aviation, or its converse, what constitutes a genuine unlevelled playing field. In fact, while ICAO has drafted a model level playing field clause, it has gone so far as to state in a March 2013 Working Paper that it "...is unlikely that consensus on a comprehensive definition can be achieved at this time, given the widely different circumstances of States and their aviation sectors..." (p.3). This is borne out by major differences in the level playing field clauses that the European Commission has negotiated with the U.S. versus Canada. This paper is an initial step to fill this gap and address ICAO's challenge to develop a comprehensive definition by articulating these issues and linking the level playing field with air transport liberalization. 


\section{Historical context}

The preamble of the Convention on International Civil Aviation (the "Chicago Convention") sets out its objective to ensure that "international civil aviation may be developed in a safe and orderly manner and that international air transport services may be established on the basis of equality of opportunity and operated soundly and economically".

Consistent with the Chicago Convention, the bilateral air services agreements that were negotiated between nations usually had some form of wording referring to the provision of "fair and equal opportunity to compete." In practice, however, governments hardly seemed willing to allow their carriers to really compete. Rather, they seemed to more heavily weigh the objectives of establishing operations that were relatively sound and economic (i.e., preventing service failures and destructive competition) than they were on actually providing equality of opportunity. This is not to say all services provided by flag carriers were economic. In the early days, and to some extent today, governments were willing to subsidize some services that were not commercially viable to achieve some other governmental purpose, such as access to low population regions. What they did not want, however, is for the carriers to actually compete with each other as that could mean even greater levels of subsidization would be necessary.

What governments appeared to seek for their respective flag carrier(s) was an "equitable" split of a pool of revenues that were based on controlled (and high - above marginal cost) fares to achieve sound and economic operations. Routes and capacity were typically divided among carriers in such a manner as to ensure each carrier could operate profitably, hopefully without subsidy. Stability and sustainability were the goals, rather than competition and market growth. Essentially, governments actually sought equality of outcome rather than equality of opportunity.

In large part, the issue of the level playing field plays an inordinately larger role in aviation than in other sectors, due to the fact that aviation has been separated from general trade negotiations. In general trade theory, it is recognized that countries may have a comparative advantage in some factors of production and markets, and comparative disadvantages in others. Higher trade in areas where they have an advantage will be offset by lower trade in areas where they do not have an advantage. The focus is on overall benefits - not in trying to make every nation equal to others in all elements. By separating aviation from the rest of trade, comparative advantage/disadvantage is more difficult to achieve, and thus LPF issues are brought into greater focus and the impact exacerbated.

An interesting example of aviation specific comparative advantage is that between Europe and the Gulf States. The Gulf states may have a comparative advantage in international hub operation between Europe and South Asia/East Africa, that has enabled the growth of Gulf carriers. But these have purchased large numbers of A380 and other Airbus aircraft. In fact, without the purchases by the Gulf carriers it seems unlikely that the A380 would have been built at all. The exercise of Gulf carriers' comparative advantage in airline hub geography has enabled Europe to benefit from its comparative advantage in high tech manufacturing and skilled labour to engage in the production of very large aircraft. Without the first, the second would not have occurred. 
In contrast, under the mercantilist approach, nations sought to boost their own economies by imposing high tariffs and imposing non-tariff barriers to protect domestic production, banning their colonies from trading with other nations, and subsidizing exports. Under such an approach, aggregate welfare is lower as comparative advantages are artificially negated.

Thus prior to the rise of open skies agreements between nations, international air transport operated under very restrictive conditions. The air service agreements between nations typically specified which city pairs could be served, and in some cases explicitly excluded certain airports. The number of carriers that could provide service was usually restricted (generally to a single carrier from each nation), as was the capacity they offered. In addition, all fares had to be approved by the civil aviation authorities of both nations party to the agreement so as to ensure proposed fares were not "unreasonably low" such that they might threaten the profitability of the carriers. This often was effected by governments allowing or requiring the carriers to agree on prices under the old tariff regime of the International Air Transport Association (IATA).

This approach began to change with the signing of the "International Air Transportation Negotiations Statement of U.S. Policy for the Conduct of the Negotiations" issued by President Carter. The statement noted:

"The guiding principle of U.S. aviation negotiation policy will be to trade competitive opportunities, rather than restrictions, with our negotiating partners. We will aggressively pursue our interests in expanded air transportation and reduced prices rather than accept the selfdefeating accommodation of protectionism. Our concessions in negotiations will be given in return for progress toward competitive objectives, and these concessions themselves will be of a liberalizing character." (Carter 1978)

A key element of the U.S. approach to open skies is that the objective of a level playing field is equality of opportunity, not equality of outcome. This is fully consistent with the objective articulated in the preamble to the Chicago Convention. Reliance on competition and reduction of the burden of regulation were the principles that would drive subsequent U.S. negotiations.

In 1978, the U.S. reached a partially liberalised air services agreement with the Netherlands, followed by liberal agreements with Israel and Belgium. After a lull in liberalization efforts during the 1980's the U.S. reached its first open skies agreement with the Netherlands in 1992. By the end of 1995, it also had open skies agreements with Belgium, Finland, Denmark, Norway, Sweden, Luxembourg, Austria, Iceland, Switzerland and the Czech Republic. Today it has open skies agreements with over 100 nations. The typical open skies agreements allows service between any point in one country to any point in the other, with no restrictions as to number of carriers or the capacity they offer. In addition to open $3^{\text {rd }}$ and $4^{\text {th }}$ freedoms, they also provide for $5^{\text {th }}$ and $6^{\text {th }}$ freedom services, and sometimes $7^{\text {th }}$ freedoms for all-cargo services. Sixth freedom services are an important part of open skies agreements as such hubbing services were often capacity restricted in traditional bilateral air service agreements. The profound economic advantages of operating hubs were effectively blocked by traditional agreements.

The concept of equality of opportunity also guided other liberalization initiatives such as the EU Common Aviation Market, the Australia-New Zealand Single Aviation Market, and the Multilateral Agreement on the Liberalization of International Air Transportation (MALIAT) between Brunei Darussalam, Chile, Cook Islands, Mongolia, New Zealand, Samoa, Singapore, Tonga and the U.S. The preamble to the MALIAT refers to the promotion of "an international aviation system based on competition among airlines in the marketplace with minimum interference and regulation". IATA's Agenda for Freedom initiative also supports the equality of opportunity concept. 
There has been some backlash to this approach of late, and an apparent desire by some to return to a greater degree of government control over aviation services. Kahn (2002) noted that there were inevitably issues stemming from deregulation/liberalization, but that the lessons from the airline, telecommunications and electric utilities industries shows "the superiority of competition over comprehensive regulation". True, it requires a greater reliance on competition law, but a return to regulatory prescription is not the answer.

Gillen, Harris and Oum (2002) modeled the economic effects of bilateral liberalization of air transport. They found in the case of Canada-Japan air services, the effects of removing regulations on price, frequency and entry would add service, lower prices and welfare gains to both Canada and Japan. InterVISTAS-ga ${ }^{2}$ (2005) quantified the results of past and prospective air service liberalization. They found that traffic growth typically averaged between 12 and $35 \%$, with some cases reaching almost $100 \%$ of pre-liberalization volumes. This has a significant stimulation effect: they found that liberalizing 320 restrictive existing agreements could generate $\$ 490$ billion in Gross Domestic Product globally. The threat to continued liberalization could have significant economic repercussions, and warrants examination of the current focus on leveling the playing field.

\section{Factors affecting the level playing field that should not be considered an issue}

Outside the classroom construct of "perfect competition" it is an anomaly to find a perfectly level playing field. For example, when Apple Computer launched its early computer products it was a fraction of the size of IBM. Many might have argued this was not a level playing field, as IBM had size and market domination that tilted the field in its favour. Yet as of early October 2014, Apple's market capitalization of over $\$ 600$ billion is significantly higher than IBM's market capitalization of just under $\$ 190$ billion (Bloomberg 2014). Perhaps the field was tilted in Apple's favour by virtue of flexibility and innovation! The key is what factors are legitimately issues in assessing a level playing field in aviation and which are not.

Wills-Johnson and Affleck (2006) address the issue of firms generating excess rents in their evaluation of Australian access to rail infrastructure. One the one hand, they note that Marshallian rents (market power rents) are inconsistent with economic efficiency, and are a legitimate concern for regulatory authorities. On the other hand, they note that Ricardian rents (resource rents, or rent that accrues to a firm due to the nature of the assets held by the firm) should not be a concern to regulators. This is because resource rents do not distort behaviour of the firm. The firm does enjoy rents, but as it does not have the ability to satisfy the entire market, it does not set the price. They also note that Schumpeterian rents (innovation rents) should not be a target for regulators. While Schumpeterian rents do in fact lead a firm to reduce output below, and raise price above, the economically efficiency level as a monopolist would do; this is the price we pay to achieve innovation. They also note that these rents tend to be short-term in nature - the fact they exist spurs other firms to innovate as well.

We consider the various elements of a level playing field from this perspective. 


\section{Geography}

Having a level playing field does NOT mean that we have to compensate for geographic advantages or disadvantages. In effect, geography is an asset - one that may generate Ricardian rents, but nothing that should be a target for regulators.

New Zealand based carriers do not have an inherent right to get special compensating advantages in bilateral air agreements because of the disadvantages inherent to that country's remote location. Nor should policy attempt to penalise countries such as Canada due to their favourable geographic location as intermediaries between major markets. The fact that flightpaths between Europe and the U.S. and between Asia and the U.S. go through Canadian airspace, making 6th freedom services by Canadian carriers through Canadian hubs attractive, should not result in limitations to such services.

The provision of capacity on a route to/from Canada to Europe (or Asia or the U.S.) greater than can be justified by pure Canadian related origin/destination traffic due to the 6th freedom traffic the Canadian carrier can flow should not be a cause for concern and remediation through bilateral air service agreement restrictions. The same would be true for other geographies, such as South-east Asia, the Middle East or Turkey. As already stated, limiting 6th freedom rights is tantamount to suppressing the economic advantages of hub and spoke systems.

Geographic advantages are natural features (resources) that enable the provision of attractive economic services. Consumers should not be denied such services by a misguided effort to negate these advantages through punitive provisions in air service agreements.

\section{Airline Size}

A level playing field does not mean that we compensate for airline size. Larger airlines might enjoy some types of economies. If so, airline size is a natural outcome of success and growth, and we should not penalize large carriers (e.g., restrict their access), nor should governments provide artificial support (i.e., subsidize) to smaller carriers in order to make large and small more equally competitive. Airline size might be an issue when evaluating mergers, but it should not be an issue when determining air access.

One might argue that if a carrier achieved its growth as a result of "unfair means" such as government subsidy, would this not be grounds for assisting smaller carriers? Aside from the impracticality of determining the magnitude of all past unfair treatments of all carriers so as to know how much support should be given to other carriers, is it really necessary to address all "past sins" before moving forward? As Rose (2012) points out, regulating well (or in this case leveling the playing field for airline size) is difficult. Rose notes that regulation is information-intensive, it can give the wrong incentives, which can lead to behaviours that the regulators then need to address, and that the cost of regulation may be greater than the market flaws it seeks to address.

In our view, the successful growth of a carrier may give it a natural comparative advantage that does not constitute an unlevel playing field.

\section{Factors of Production}

A level playing field also does not mean that we have to equalise factor of production advantages. For example, the U.S. should not and does not get special privileges vis á vis Canada because latter has lower labour costs and/or provides a higher level of social services such as national health care. 
The same applies for lower fuel costs. They are lower in some places than others due to location of sources and production and/or national taxation policies towards crude oil production (aviation fuel sales for international services are exempt oil product duties in all countries in line with ICAO's 1993 Resolution). As long as there is no discrimination of rates between domestic and foreign operators, this should not be an issue.

Airport charges vary among airports around the world. Much of the difference stems from government policy. In the case of Toronto Pearson relative to competing U.S. hubs for services to Europe and Asia, the Canadian Government requires the airport operator to cover all capital and operating costs and it charges in excess of $\mathrm{C} \$ 100$ million in annual rent even though it provides no services to the airport operator that are typical of a landlord. The policy of the U.S., on the other hand, is to support the growth of aviation by the provision of the necessary infrastructure to foster growth. U.S. airports enjoy tax-free bond financing, generally pay no rent for access to the land and no property taxes, and air travellers (and shippers) benefit from capital grants to aviation infrastructure that are funded in part through general tax revenues. Since 1971, the U.S. Federal Aviation Administration (FAA) has received funding from the general fund (i.e. general taxes) in excess of $\$ 163$ billion (expressed in 2013 dollars) to fund air traffic control and airport infrastructure. There could be a cause for redress if US airports discriminated against foreign-based airlines. However, since a given aircraft type pays the same airport fees whether the carrier be from Asia, the EU, the US or a Gulf State, the low landing fees in the U.S. are not a valid basis for retaliatory actions. It should be noted that other nations support aviation infrastructure as well, including air traffic control services.

Cost of capital may vary across airlines, due to factors such as risk. Risk may vary across carriers based on geographic location, the quality of management, the soundness of the business plan and the degree of competition in the market. Again, it makes no economic sense to try to negate advantages lower risk airlines might have over higher risk carriers by equalizing cost of capital. To the contrary, intervening in the market for risk to level the playing field could be very detrimental to economic efficiency.

Corporate and other taxes paid by a carrier to its home government are another element that is outside of the definition of level playing field. One interesting aspect of taxation is the view held by some that high tax nations tilt the playing field to the disadvantage of their own home carriers. If a given government taxes aviation more heavily than other nations, that is its prerogative. It does not justify restricting access by carriers from nations with lower tax rates in order to offset the disadvantages it chooses to impose on its flag carrier(s). Of course, foreign carriers should face the same tax rates as domestic carriers, where applicable.

Any cost advantages a carrier enjoys based on its geographic location, quality of management, cost of capital, or level of taxation of its base country(ies) is not an element that should be addressed in trying to level the playing field. These elements are more akin to assets or resources that could potentially lead to Ricardian rents, but are not issues that should be targets of regulation via air service agreement restrictions.

\section{$6^{\text {th }}$ freedom traffic}

One claim that arises (e.g., especially vis á vis Gulf carriers) is that 6th freedom traffic creates an unlevel playing field. Proponents of this view maintain traffic rights should be confined only to 3rd/4th freedom traffic. Sometimes this is expressed as capacity should be limited to that needed to meet the needs of $3 \mathrm{rd} / 4$ th freedom traffic between the city-pair market, and not for any connecting traffic to beyond points. This represents the mercantilist approach of capacity predetermination found in traditional bilateral air service agreements. 
First, restrictions on 6th freedom traffic are a violation of open skies principles. Open Skies is explicit in allowing unrestricted 6th freedom traffic. After all, a carrier operating 6th freedom services is really only combining 4th and 3rd freedom traffic rights between markets it has a right to serve. Exploiting 6th freedom opportunities does not represent an unfair activity and thus does not constitute a playing field that is not level.

Second, restricting 6th freedom traffic is an attempt to suppress the economics of hub operation. This is akin to attempting to compensate for geography, an asset that is a natural element of comparative advantage.

Third, it is interesting to note that carriers making such a criticism often operate their own sixth freedom service or are in an alliance with another carrier operating 6th freedom flights. Criticisms that state that Gulf carriers should have their capacity limited only to what is justified by $3 \mathrm{rd} / 4$ th freedom traffic often come from carriers operating their own major 6th freedom hubs, for example service traffic from the U.S. to Europe and/or Asia (and vice versa). These carriers may even point this out to investors as being part of its core strategy for success - the carrier emphasises its natural geographic advantage that allows it to operate an efficient hub for moving traffic between different regions. 6th freedom is the very concept of international hubbing. The economics are the same for a domestic hub vs 6th freedom operation for international services. If a hub is located where it can serve many spokes, this is not evidence of a legitimate concern about the playing field - it is simply a natural comparative advantage.

This echoes an earlier point. Geographic advantages do not create an unlevel playing field, requiring correction. If we were to try to equalise the outcome, then Canada should be restricted in its bilaterals to offset its natural geographic advantage between the large markets of the U.S., Europe and Asia. The same would then have to be true for all countries with carriers that have successful international hubs, such as Heathrow, Schiphol, Frankfurt, Charles de Gaulle, Istanbul, the Gulf States, Singapore, Hong Kong, Atlanta and others. When governments venture into equalising geographic advantages via restrictions, we move from an equality of opportunity regime to one of equality of outcome. This is a move to mercantilism.

\section{Airport Slots}

The level playing field concept does raise issues regarding access to scarce resources, especially slots. But we cannot expect to equalise slots between nations via bilateral air service agreements. What policy should do, however, is give some preference to new entrants for slot access, while not completely holding back growth of the incumbents. The IATA slot guidelines and similar policies of US, Canada, UK etc. which makes some but not complete accommodation for new entrants when slots become available has merit in that it partially levels the playing field.

Some bilateral air service agreements have provided some slots as the initial situation is severely distorted favouring one carrier. For example, when Canada and the U.S. signed their first open skies treaty, the U.S. agreed to provide Canadian carriers with a small number of initial slots at New York LaGuardia airport. Multiple U.S. carriers had access to this airport for years and could easily internally reallocate their slots to Canadian services. Canadian carriers would have been at a significant disadvantage for years until they were able to obtain slots as they came available through the normal process. Thus, the U.S. agreed to a small initial allocation of slots to Canadian carriers, after which they would have to obtain slots via the normal queuing process or by slot sales/exchanges.

But we can go further and suggest that a level playing field is enhanced if slot access has market elements. Carriers should be able to buy and sell slots, enabling carriers who place highest values on 
the slots to get access. Scarcity is a consequence of not allowing proper pricing of scarce resources. There is competition law to address failures to allow access; bilateral air service agreements are not the appropriate tool to address this issue.

\section{Legitimate Concerns Raised by Level Playing Field}

\section{Improper Incentives and Flags of Convenience}

The goal of a level playing field does raise issues of safety and proper incentives. It is appropriate for bilateral air service agreements to require carriers to conform to both countries' safety regulations (i.e., it must obtain an operating certificate/license from both countries). We do not want to create incentives for carriers to compete by adhering only to the lowest common denominator on safety. While this may occur in maritime freight shipping, protecting passengers outweighs cost savings. We want the opposite behaviour to occur: carriers adhering to the highest denominator of safety. Any cost advantage derived from exploitation of weak safety rules or inadequate compliance should not be allowed.

This also applies to labour regulations, though this issue is more complex. Carrier ground staff based within a given country must adhere to that country's labour laws. Again, we do not want to promote the development of flags of convenience which might exploit labour utilizing sub-standard labour laws or lax enforcement of labour standards of a third country (e.g., that would directly or indirectly permit child labour). However, when it comes to flight crew labour that operates on routes to various countries, carriers should be free to choose their bases and be allowed to operate multiple bases within their route networks. The EU, in its communication addressing future challenges for its external aviation policy (COM (2102) 556 final) indicates that the practice of "using the least onerous social security systems irrespective of the crew member's home base can no longer be continued." (para 25). We would agree that crews based in a given country should not have social security systems applied that are to lower standards than that of the country in which the crew is based. However, we should not be dictating to foreign airlines which countries they should choose for crew bases in an attempt to make sure their costs are inflated to the benefit of the home carriers.

Bilateral air service agreements should not prevent, for example, Qantas from establishing London based flight crews who may be U.K., not Australian, citizens. Cathay Pacific found it economic to establish pilot and flight attendant bases in Canada in spite of lower general wages in Hong Kong. The hiring of these crews and the standards of their working conditions must adhere to local labour laws, including regulations on duty times, etc. the same as locally domiciled carriers must follow. Collective bargaining between a carrier and its unions might seek to prevent foreign hired and domiciled flight crews, but this is not the role of the bilateral air service agreement to address by imposing restrictions on carriers that use foreign hired and domiciled crews. Equality of opportunity should prevail in air service agreements. If Qantas finds it economic to base crews in London who adhere to the same labour rules as its competitors who are based in London, then the bilateral should not prevent this. Again, collective bargaining may seek to limit carrier choices, but failure at collective bargain should not be allowed redress through the regulatory mechanism of bilateral air service agreements. Bilateral air service agreements should not be used to compensate home carriers for any 
failures they suffer in different fora. They should remain mechanisms for offering consumer choice and facilitating market growth rather than balancing outcomes between carriers.

\section{Subsidies}

The issue of subsidies is complex. The existence of wider economic benefits from aviation can justify some type of support to air transport in order to obtain economic efficiency. Many nations provide such support to infrastructure operators (airports and air navigation). For example, the US FAA is funded by both aviation-specific user fees and taxes as well as by allocations from general taxes (or government deficits) to cover airport capital costs and air traffic control costs. U.S. airports in particular have access to tax free debt financing. In this form, since all carriers benefit from the lower cost of airport/air navigation services, this would not necessarily constitute an unlevel playing field. If the criterion for such support is that the benefits derived from the infrastructure investments outweigh their costs, then subsidy might be justified.

This type of support is different from subsidies to specific carriers. Carrier-specific subsidies distort allocative efficiency and create incentives for X-inefficiency (i.e., when firms do not have incentive to minimize costs and achieve technical efficiency). This has been an issue for some stateowned carriers prior to (and sometimes after) privatisation, although state ownership of an airline does not necessarily imply the existence of subsidization.

There can be justifications for support direct to carriers, such as in provisions of socially required services that are uneconomic (e.g. to remote airports). Europe has provided guidelines on state aid to carriers. It does not prohibit government ownership of carriers and airports (this means that governments can invest in carriers and airports), but government can no longer subsidise them to create an unfair cost advantage for a particular carrier. It allows governments to subsidise socially required air services, but the subsidies must be transparent and non-discriminatory. The U.S. has government ownership of airports but this does not create an unlevel playing field. These facilities are used by all carriers and access/fees are non-discriminatory. Again, a key guiding principle of a level playing field is that access is non-discriminatory.

In the case where a subsidy is needed for a socially required air service, but the subsidy is available to any carrier and is awarded on the basis of an open competition, it could be argued that this does not violate the level playing field. Tendering ensures that the subsidized service outcome is as economically efficient as possible. In a situation where a carrier does receive a subsidy from government (other than for socially required services) and that this subsidy is not available to others, or is not awarded on the basis of a tender, this could constitute a legitimate concern about the playing field and would require further investigation.

This suggests that there are two main issues here. The first is whether certain carriers are subsidised or not, and the second is whether any subsidy that does in fact exist distorts the market.

Extent of subsidy. The most commonly cited claims of "subsidised" airlines concern the three growing airlines from the Gulf States: Emirates, Etihad Airways, and Qatar Airways. These accusations have never been convincingly substantiated. The heads of all three airlines have unequivocally and publicly stated that while they enjoy an environment where aviation growth is facilitated, they do not receive subsidies. Emirates acknowledges some financial support from the government at start-up in the form of an initial equity investment, but this is not an uncommon occurrence. Indeed most of the airlines making allegations of Gulf carrier subsidies started via government equity investment. Moreover, as Emirates points out, the US \$2.3 billion it has paid in dividends to the Government of Dubai more than compensates for the $\$ 10$ million in seed capital and 
$\$ 88$ million in infrastructure investment. (Emirates, p.8) In this case, at least, the existence of subsidisation seems far from established.

Does any subsidy that might exist represent bad economics? The issue of subsidy in discussions of level playing field needs to treated carefully. Subsidies are not bad economics per se. As discussed, there can be sound economic rationale for the provision of subsidy in certain cases.

The World Trade Organization (WTO) notes that when the perfect market assumptions do not hold, then:

“...situations may arise where a government measure like a subsidy improves welfare. An efficient subsidy would correct a market failure, bringing social and private costs and benefits into alignment." (WTO, p. 55)

The WTO goes on to describe two examples that would justify public subsidies. The first is increasing returns to scale particularly where there is a large fixed cost of entry, and the second is externalities. (WTO, pp. 58-62) Airports are generally characterized by economies of scale and large entry costs. Moreover, airline service has a positive form of externality as increased connectivity has a positive impact on a nation's productivity, although there are also negative externalities associated with noise and emissions. In these cases, support for the development of airports and for the operation of airlines would in fact be socially desirable.

Regarding state aid to carriers, the carriers of the European Union are subject to enforcement of a State aid regime, perhaps the only trading bock in the world which has such a regime. Some claim that the WTO rules are loose and largely unenforceable, hence the European Commission's wish to amend Regulation 868/2004. This is not to say that there are no national rules in other countries which govern subsidies, but it is hard to compare a fully-fledged State aid regime and State aid control mechanism Europe has developed with somewhat disparate national rules. The U.S. for example has provided support to carriers for "essential air services" and for effects of traffic disruptions due to terrorism. It has provided support from the General Fund to airports and/or to air navigation services.

Thus the onus should be on those alleging "unfair" subsidisation to show that in fact this subsidisation does exist ant that it lowers consumer welfare. There is no evidence to date that this is the case. General support of aviation and public investment in infrastructure are activities that forward looking and private sector growth oriented governments are pursuing. Simply because the EU has chosen to apply strict State aid controls that go beyond the WTO's anti-subsidy provisions does not mean that nations abiding by less restrictive WTO provisions are discriminating against European carriers. The fact that the EU made a policy choice to be more strictly prohibitive of State aid does not mean the rest of the world has to abide by EU rules and stop supporting aviation infrastructure when there are good economic reasons for such subsidy.

Beyond the potential economic rationale for subsidies, there are also legitimate social/national reasons why a government might wish to subsidize air transport. Lebanon and Israel both have social goals of requiring a minimum level of service in times of national strife in order to remain connected to the rest of the world. This in turn may justify a degree of social support for their home based carriers in order to preserve that accessibility. The U.S., for defence reasons, maintains the Civil Reserve Air Fleet to ensure it has sufficient airlift capacity in time of war or other national emergency. In exchange for a commitment to provide aircraft when needed, airlines get access to peacetime airlift business of the US military. There can be a number of reasons for support of airlines, beyond a strictly economic rationale. 



\section{Liberalization and the level playing field}

Some have argued that open skies, or extensive liberalization of international air transport enables the tilting of the playing field in favour on one carrier or another. If what is meant by "tilting the playing field" is allowing certain carriers to take advantage of their geographic location, their size, possible advantages in the cost of factors of production, an ability to offer attractive $6^{\text {th }}$ freedom operations, use of superior technology or legitimate access to scarce resources, then we should not view that such a playing field is "unlevel." To attempt to level all such comparative advantages to the logical conclusion, the way to achieve a truly "level" playing field would be by commoditizing international air transport and locking it into the lowest common denominator status quo. After all, can it really be considered a "level" playing field if one competitor is better than another? Surely for those seeking equality of outcome, a playing field with competitors of different capability is by definition not level. Unfortunately, it is easier to bring carriers down to the lowest common denominator than it is to raise all carriers to the highest level. Creating a truly level playing field would inevitably result in a poorer level of service for travellers and shippers. A good example of such misguided leveling of the playing field is the past episode when the size of sandwiches on international flights was regulated. (Kahn 2000)

If, on the other hand, we take as a given, that carriers should be allowed to capitalize on their natural inherent advantages, then open skies or other such significant liberalization, is a necessary condition for a level playing field. Under these conditions, carriers can actually compete on the playing field. The historical Bermuda II approach, naming available points for service, specifying capacity and tying capacity to origin/destination volumes may result in a "level playing field," but only in the sense that the rules restrict the players from actually playing. The field is level because the outcome is predetermined - there is no actual "game" being played on the playing field.

The purpose of a "fair competition clause" such as the EU is seeking in its bilateral air service agreements to ensure this level playing field only really makes sense in an open skies environment, where competition is possible. Having a fair competition clause in a restrictive bilateral is an oxymoron - fair competition is not possible under a restrictive agreement where government decides what services and capacity are to be provided rather than the marketplace. Fair competition clauses could even cause some potential confusion. This could occur if there is a conflict between the wording used in the air services agreement and wording used in the two nations' competition or trade laws.

What is implicit in this argument is the existence of effective competition law that can address actual situations of abuse of market power. The proper application of effective competition law is sufficient to address predation, dumping and other unfair and anti-competitive practices. "Fair competition" clauses are not necessary. While a number of nations admittedly have some way to go in achieving effective competition law (given some nations do not have any laws, or exempt aviation from them), curtailing abuse of market power will be more likely in situations of Open Skies where competitive forces will act to prevent abuse. A return to more restrictive access, particularly in the absence of effective competition law will not be of benefit to passengers or shippers. 


\section{Alliances, anti-trust immunity and the level playing field}

One possible element of international air transport that could potentially tilt the playing field is the evolution and future actions of the global airline alliances. Alliance building (or deconstruction) may be affected by potential cross-border mergers/acquisitions if ownership rules are relaxed. The discussion below focuses on alliances, but the same arguments would hold for global carriers created through mergers or acquisitions.

In the early days of alliances in the 1990s, there were a number of budding global alliances, some of which eventually evolved into the three branded global alliances: Star, oneWorld and Skyteam. These alliances formed as a means of establishing a global network in a regulatory environment which did not allow mergers or acquisitions of carriers across borders. Northwest, Continental and KLM (Wings) kick-started the process, and were soon joined by United/Lufthansa/Air Canada/SAS/Thai Airways (Star), as well as Delta/Swiss/Sabena/Austrian (Atlantic Excellence) and American/Canadian/British Airways/Cathay/Qantas (oneworld). The key members of Wings and Atlantic Excellence eventually combined into SkyTeam and Wings ceased to be (it was never actually a formal association though they did co-operate) as did Atlantic Excellence. We are now down to three global alliances.

Regulator acceptance of these alliances, especially those requiring the granting of anti-trust immunity, has generally been tied to open skies. Giving large immunized alliances access to a market characterized by restrictive traffic rights could be a recipe for carrier exercise of market power. Open skies or a similar regime with access for potential new carriers is a necessary condition for anti-trust immunity to be granted to an alliance.

Dealing with actual, or potential, abuse of market power, however, should not be done through the mechanism of air service agreements. This is better done by general competition law rather than by sector specific bilateral treaties.

It should be noted also that competition law is applied differently in different jurisdictions. The EU would prefer that competition authorities be independent. However, different States will apply competition law in different ways. For example, in the U.S., while the various anti-trust laws are generally administered by the Department of Justice, in the case of airline alliances/ mergers/ acquisitions, the Department of Transportation has jurisdiction. Moreover, many States will assess alliances or mergers/acquisitions from more than the perspective of economic efficiency that competition law generally adopts. In Canada, for example, the Minister of Transport has a role in these assessments in order to balance national interests with the economic efficiency focus the Canadian Competition Bureau adopts. In New Zealand, the Transport Minister is responsible for alliance authorizations in order to achieve this same balance between economic efficiency gains and national interests. A one-size-fits-all approach for application of competition law to aviation is not likely an achievable goal. 


\section{A final implication of having a level playing field}

Finally, it should also be noted that the allegory of the "level playing field" can be misleading. Just because a playing field is level does not mean that every game will have teams that do equally well and end in a tie score - there is more likely to be a victor than a draw. Level playing fields can and do generate winners. Moreover, the sports analogy is a zero-sum game. The experience of Low Cost Carriers (LCCs) clearly illustrates that aviation is not a zero-sum game. New entry by LCCs with low fares has brought new travellers into the market, increasing the size of the pie for which the carriers compete. In aviation, gains by one airline can actually benefit another by stimulating the overall market, enabling other carriers to gain incremental traffic, if not market share.

\section{Conclusions}

The concern about a level playing field has raised its profile in aviation in recent years, yet few have defined what constitutes a level playing field, or alternatively, what makes a playing field unlevel.

In this paper we review elements that are often cited in arguments about whether access should or should not be granted, and on what terms. We find the following do not constitute legitimate factors that should be addressed in an air services agreement in order to make a playing field "level":

- Geographic advantage/disadvantage;

- Size of carrier;

- Differences in the cost of factors of production;

- $6^{\text {th }}$ freedom traffic opportunities;

- Technological advantage; and

- Airport slots.

Legitimate areas of concern include safety and general carrier-specific subsidies. The latter concern does not include transparent subsidies for specific air service obligations, especially if eligibility for such subsidy is competitive and non-discriminatory. It also does not exclude economically efficient subsidies to infrastructure.

There is a need to keep watch on developments in global alliances, or potential cross-border mergers and acquisitions, to ensure the resulting carrier combinations do not engage in activities that constitute an abuse of market power. The mechanism to deal with this, however, is through the application of competition law. It should not be addressed by bilateral air service agreements. 
Many of the complaints heard today are attempts to negate natural inherent competitive advantages. This effectively seeks to deny consumers the benefits of lower costs and/or better service that arise from geographic, management and other legitimate advantages inherent to a number of air carriers.

\section{Future areas for consideration}

This paper represents an initial look at what does and does not constitute a legitimate concern regarding the level playing field. It also looks at the role of liberalization of air bilateral agreements in preventing the market abuse some wish to address by restricting access through leveling the playing field.

The issues covered above are a first cut. There are other factors that could also be brought into the discussion. What about interventions in the market to maintain capacity that might be needed for national emergency response purposes? Does the provision of war risk insurance tilt the playing field? U.S. Chapter 11 bankruptcy protection and similar provisions elsewhere, are potential issues. Variation in personal income tax (rather than corporate taxes discussed above) may be another issue. The role of foreign ownership restrictions is potentially a factor to be considered. The theory of comparative advantage in international trade does not require that citizens of one country can purchase assets in another country, but such ownership provisions can enable better exploitation of economies of scale (if they exist) and utilisation of comparative geographic advantages. These and other issues will be the focus of future work. 


\section{References}

Air Line Pilots Association White Paper, "Leveling the Playing Field for U.S. Airlines and Their Employees", 2012.

Arab Civil Aviation Commission, "Agreement for the Liberalization of Air Transport Between the Arab States."

Bloomberg, 2014. According to Bloomberg's website summaries of the two companies on 9 October 2014, Apple's market cap was $\$ 608,127.77$ million USD while IBM's was $187,736.87$ million USD.

Carter, Jimmy, "International Air Transportation Negotiations Statement of U.S. Policy for the Conduct of the Negotiations", August 21, 1978.

De Wit, Jaap G., "Unlevel playing field? Ah yes, you mean protectionism", Journal of Air Transport Management, 2013.

Dresner, Martin E., "The International Regulation of Air Transport: Changing Regimes and Price Effects," $\mathrm{PhD}$ dissertation, University of British Columbia, 1989.

Emirates, “Airlines and subsidy: out position,” 2014. Available at http://www.emirates.com/english/images/airlines\%20and\%20subsidy\%20\%20our\%20position\%20new_tcm233-845771.pdf

$\mathrm{EU}$, in its communication addressing future challenges for its external aviation policy (COM (2102) 556 final)

Findlay, Christopher and Andrea Goldstein, "Liberalization and Foreign Direct Investment in Asian Transport Systems", Asian Development Review, January, 2004.

Gillen, David, Richard Harris and Tae Hoon Oum, "Measuring the economic effects of bilateral liberalization air transport", Transportation Research Part \# 38, 2002.

International Civil Aviation Organization, "Convention on International Civil Aviation", signed at Chicago, on 7 December 1944.

International Civil Aviation Organization, "Fair Competition in International Air Transport", Working Paper, Worldwide Air Transport Conference (ATCONF), Sixth Meeting, Montréal, 18 to 22 March 2013.

InterVISTAS-ga ${ }^{2}$, “The Economic Impact of Air Service Liberalization”, 2005.

Kahn, Alfred E., "The Deregulatory Tar Baby: The Precarious Balance Between Regulation and Deregulation, 1970-2000 and Henceforth", Journal of Regulatory Economics 21:1, 2002.

Kahn, Alfred E, Interview in The First Measured Century, Public Broadcasting Services. Text of interview is available at http://www.pbs.org/fmc/interviews/kahn.htm. 2000.

Rose, Nancy L., "After Arline Deregulation and Alfred E. Kahn:, American Economic Review: Papers and Proceedings, 2012.

Wills-Johnson, Nick and Fred Affleck, "A problem looking for a solution or a solution looking for a problem? Economic regulation of railways in logistics chains", $29^{\text {th }}$ Australasian Transport Research Forum, 2006.

World Trade Organization, World Trade Report, 2006. 
